\title{
Iminocoumarin-based Hg(II) Ion Probe
}

\author{
Hyun Jung Kim, Youngmee Kim, ${ }^{\dagger}$ Sung Jin Kim, ${ }^{\dagger}$ Sun Young Park, Su Yeon Lee, Ja Hyung Kim, \\ Kwanghyun No,,$* *$ and Jong Seung Kim* \\ Department of Chemistry, Korea University, Seoul 136-701, Korea. *E-mail: jongskim@korea.ac.kr \\ ${ }^{\dagger}$ Department of Chemistry and Division of Nano Sciences, Ewha Womans University, Seoul 120-750, Korea \\ ${ }^{\star}$ Department of Chemistry, Sookmyung Womens University, Seoul 140-742, Korea. *E-mail: hyun@sookmyung.ac.kr \\ Received November 19, 2009, Accepted November 23, 2009
}

Key Words: Fluorescence, $\mathrm{Hg}^{2+}$ ion, Complexation

The design and synthesis of new chemosensors for heavy and transition metal ions (HTM) has been an important subject in the field of supramolecular chemistry due to their fundamental role in biological, environmental, and chemical processes. ${ }^{1}$ Particularly, the recognition and detection of $\mathrm{Hg}^{2+}$ are of growing interest because the $\mathrm{Hg}^{2+}$ is considered highly noxious elements. ${ }^{2}$ Many analytical methods have been applied for this purpose including atomic absorption spectrometry (AAS), ${ }^{3 \mathrm{a}}$ ion selective electrodes (ISE), ${ }^{3 \mathrm{~b}}$ and flame photometry. ${ }^{\mathrm{c}}$ In addition, for the detection of HTM (heavy and transition metal), colorimetric sensors have also gained interest. The colorimetric sensors have considerable advantages over other molecular sen-
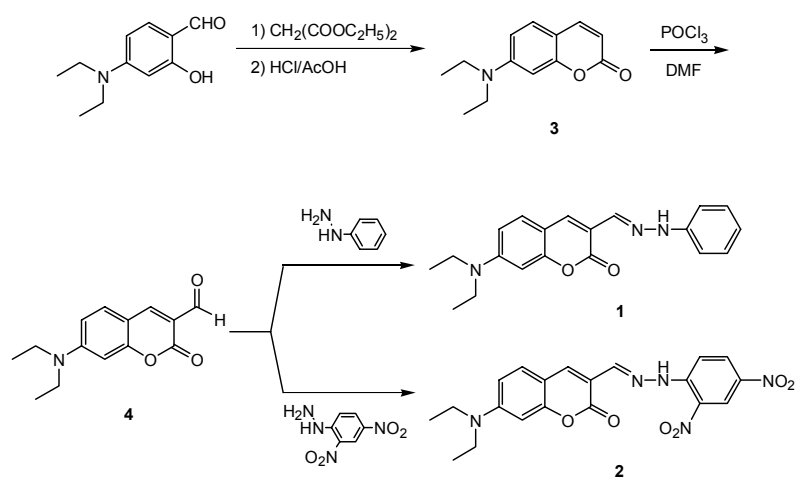

Scheme 1. Synthetic routes to 1 and 2.

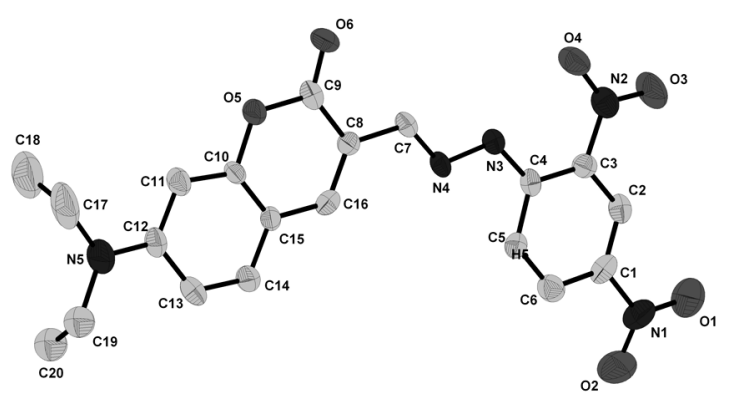

Figure 1. Crystal structure of 2. sors because they do not require the use of costly equipment such as spectrophotometers, ISE, or cyclic voltameters. ${ }^{3 \mathrm{~d}}$ So, to develop simple-to-use and naked-eye diagnostic tool, great efforts have been made for the design and synthesis of selective chromogenic sensors for $\mathrm{Hg}^{2+}$.

Coumarin derivatives have usually been used as fluorogenic sensors for cations or anions due to their high quantum yields. ${ }^{4}$ However, coumarin chromogenic chemosensors showing color changes upon certain ion complexation are rare. ${ }^{5}$ In this paper, we report new $\mathrm{Hg}^{2+}$-selective chromogenic coumarin derivative showing unique UV spectroscopic changes and obvious color changes along with enhanced fluorescence upon $\mathrm{Hg}^{2+}$ binding.

(a)

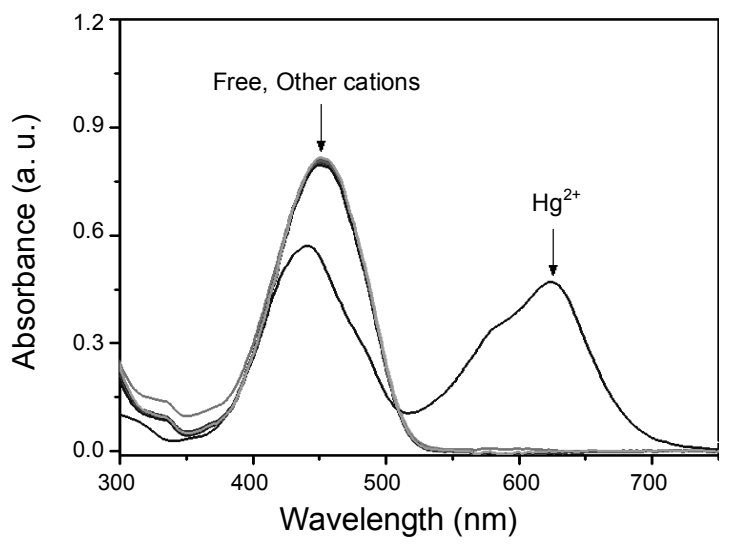

(b)

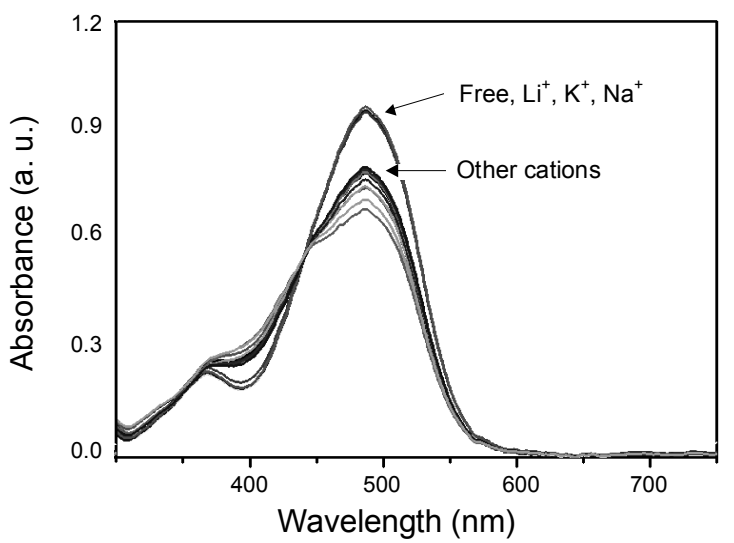

Figure 2. UV/Vis spectra of $\mathbf{1}(\mathrm{a})$ and $\mathbf{2}(\mathrm{b})(20.0 \mu \mathrm{M})$ upon addition of $\mathrm{ClO}_{4}{ }^{-}$salts of $\mathrm{Li}^{+}, \mathrm{Na}^{+}, \mathrm{K}^{+}, \mathrm{Rb}^{+}, \mathrm{Cs}^{+}, \mathrm{Cd}^{2+}, \mathrm{Ag}^{+}, \mathrm{Pb}^{2+}, \mathrm{Zn}^{2+}, \mathrm{Sr}^{2+}, \mathrm{Ba}^{2+}$, $\mathrm{Ca}^{2+}, \mathrm{Hg}^{2+}$, and $\mathrm{Al}^{3+}$ (50 equiv) in $\mathrm{CH}_{3} \mathrm{CN}$. 


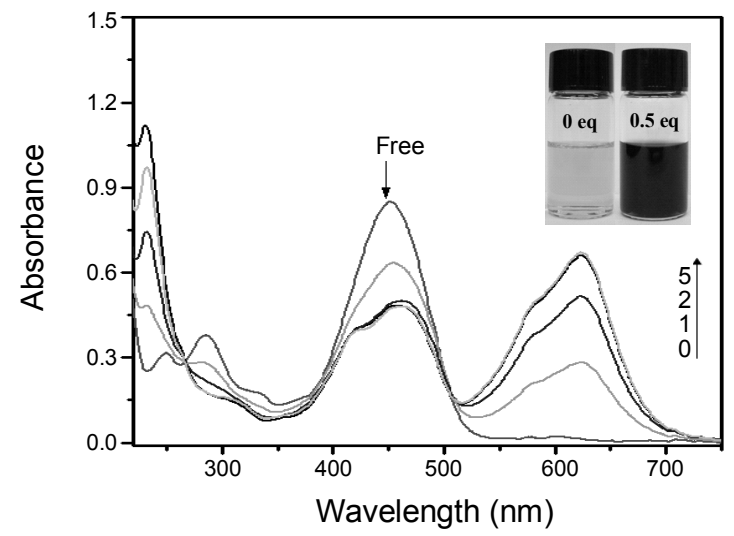

Figure 3. UV/Vis absorption spectra of $1(20 \mu \mathrm{M})$ upon the addition of various amounts of $\mathrm{Hg}^{2+}$ in $\mathrm{CH}_{3} \mathrm{CN}$ and its color change.

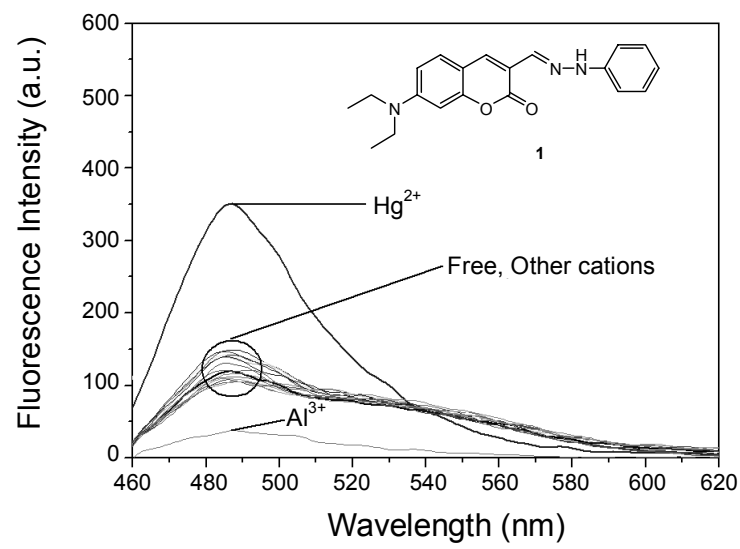

Figure 4. Fluorescence spectra of $1(6.0 \mu \mathrm{M})$ upon addition of $\mathrm{ClO}_{4}{ }^{-}$ salts of $\mathrm{Li}^{+}, \mathrm{Na}^{+}, \mathrm{K}^{+}, \mathrm{Rb}^{+}, \mathrm{Cs}^{+}, \mathrm{Cd}^{2+}, \mathrm{Ag}^{+}, \mathrm{Pb}^{2+}, \mathrm{Zn}^{2+}, \mathrm{Sr}^{2+}, \mathrm{Ba}^{2+}, \mathrm{Ca}^{2+}$, $\mathrm{Hg}^{2+}$, and $\mathrm{Al}^{3+}$ (50 equiv) with an excitation at $450 \mathrm{~nm}$ in $\mathrm{CH}_{3} \mathrm{CN}$.

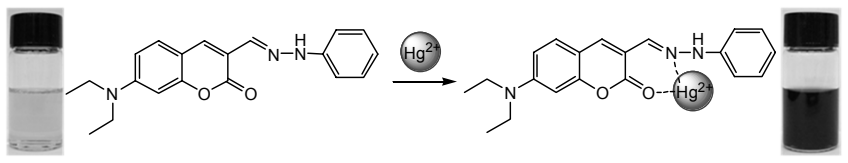

Scheme 2. Plausible complexation mechanism of $\mathbf{1}$ with $\mathrm{Hg}^{2+}$ ion.

Chromo-fluorogenic sensors 1 and $\mathbf{2}$ were prepared by 3 -step synthetic route as indicated in Scheme 1. 7-N,N-Diethylaminocoumarin (3) was prepared by adaptation of reported procedures. ${ }^{6}$ Compound $\mathbf{4}$ was synthesized in $70 \%$ yield by the reaction of $\mathbf{3}$ with $\mathrm{POCl}_{3}$ in DMF. Imination of $\mathbf{4}$ with phenylhydrazine and (2,4-dinitrophenyl)hydrazine in ethanol gave 1 and $\mathbf{2}$ in 80 and $81 \%$ yields, respectively. ${ }^{1} \mathrm{H}-\mathrm{NMR},{ }^{13} \mathrm{C}$-NMR, FR- IR and FAB-MS spectroscopies for $\mathbf{1}$ and $\mathbf{2}$ are characterized in detail in the experimental section. Also, the solid-state structure of $\mathbf{2}$ provided a convincing evidence for its 3-D conformation.

The perchlorate salts of $\mathrm{Li}^{+}, \mathrm{Na}^{+}, \mathrm{K}^{+}, \mathrm{Rb}^{+}, \mathrm{Cs}^{+}, \mathrm{Cd}^{2+}, \mathrm{Ag}^{+}$, $\mathrm{Pb}^{2+}, \mathrm{Zn}^{2+}, \mathrm{Sr}^{2+}, \mathrm{Ba}^{2+}, \mathrm{Ca}^{2+}, \mathrm{Hg}^{2+}$, and $\mathrm{Al}^{3+}$ ions were used to investigate the metal ion binding properties of both $\mathbf{1}$ and $\mathbf{2}$ in regard of absorption and emission changes. Figure 2 shows the UV-Vis spectral changes of $\mathbf{1}(20 \mu \mathrm{M})$ and $\mathbf{2}(20 \mu \mathrm{M})$, respec-

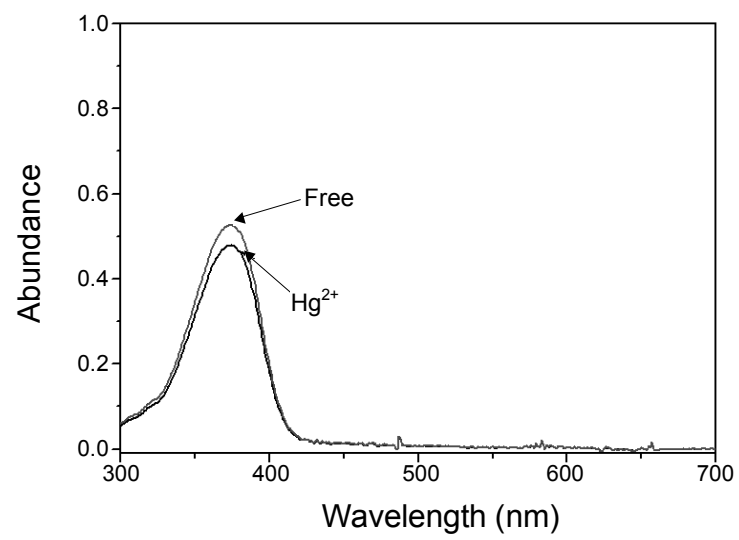

Figure 5. UV/Vis spectra of $3(20.0 \mu \mathrm{M})$ upon addition of $\mathrm{ClO}_{4}{ }^{-}$salts of $\mathrm{Hg}^{2+}$ (50 equiv) in $\mathrm{CH}_{3} \mathrm{CN}$.

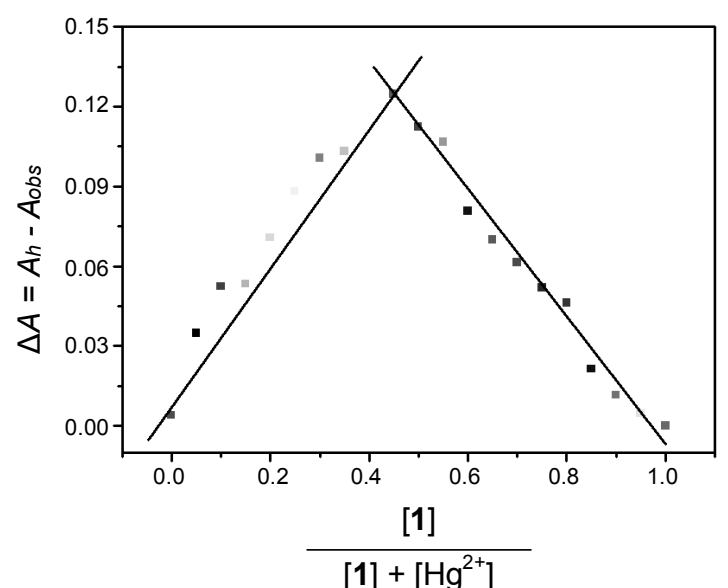

Figure 6. Job plot of 1 with $\mathrm{Hg}^{2+}$ in $\mathrm{CH}_{3} \mathrm{CN} . \Delta A=A_{h}-A_{\text {obs }}$, where $A_{\text {obs }}$ and $A_{h}$ denote the absorbance at $450 \mathrm{~nm}$ upon the $\mathrm{Hg}^{2+}$ ion binding and that of free ligand $\mathbf{1}$, respectively.

tively, upon the addition of various metal ions in $\mathrm{CH}_{3} \mathrm{CN}$. UV/ Vis band of at $450 \mathrm{~nm}$ bathochromically moved to $658 \mathrm{~nm}$ by $208 \mathrm{~nm}$ upon addition of $\mathrm{Hg}^{2+}$ ion while no changes with other metal cations are noted. However, spectral changes of $\mathbf{2}$ having two nitro units are substituted on the aromatic ring were not seen by any other metal ions. As shown in crystal structure in Figure 1, we assume that it is difficult for $\mathbf{2}$ to encapsulate a metal cation in regard of a geometrical disagreement where the distance between oxygen atom of $\mathrm{C}=\mathrm{O}$ and nitrogen atom of $\mathrm{C}=\mathrm{N}$ group of $\mathbf{2}$ is too long.

Figure 3 shows a UV/Vis spectral variation of 1 upon the gradual addition of $\mathrm{Hg}\left(\mathrm{ClO}_{4}\right)_{2}$. A considerable red-shift of absorption spectrum in $\mathbf{1}$ is presumably due to $\mathrm{Hg}^{2+}$ ion binding to carbonyl oxygen of the coumarin along with nitrogen of the $\mathrm{C}=\mathrm{N}$ unit, reflecting an enhanced intramolecular charge transfer (ICT) 7 process from $N, N$-diethyl unit to carbonyl oxygen group. The variation of fluorescence spectra of $\mathbf{1}$ upon addition of diverse cations were recorded in $\mathrm{CH}_{3} \mathrm{CN}$ and are displayed in Figure 4.

The weak emission of solution $\mathbf{1}$ is presumably due to a nonradiative decay through $\mathrm{C}=\mathrm{N}$ dynamic isomerization as was previously suggested, ${ }^{6}$ whereas the strong emission at $485 \mathrm{~nm}$ 


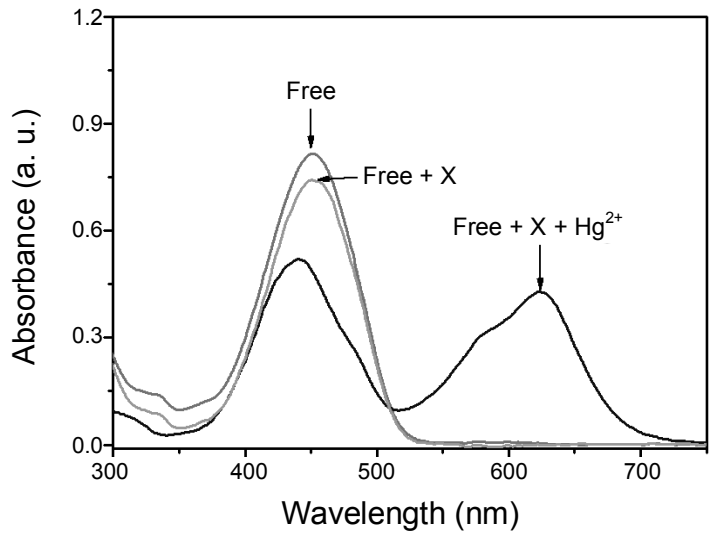

Figure 7. Absorbance spectra of $\mathbf{1}(20.0 \mu \mathrm{M})$ in $\mathrm{CH}_{3} \mathrm{CN}$ in the presence of the $\mathrm{Hg}^{2+}$ ion and miscellaneous cations including $\mathrm{Li}^{+}, \mathrm{Na}^{+}, \mathrm{K}^{+}, \mathrm{Rb}^{+}$, $\mathrm{Cs}^{+}, \mathrm{Cd}^{2+}, \mathrm{Ag}^{+}, \mathrm{Mg}^{2+}, \mathrm{Ca}^{2+}, \mathrm{Sr}^{2+}, \mathrm{Ba}^{2+}, \mathrm{Zn}^{2+}, \mathrm{Pb}^{2+}, \mathrm{Co}^{2+}$, and $\mathrm{Al}^{3+}(10$ equiv, respectively).

in the presence of $\mathrm{Hg}^{2+}$ may arise from the blocking of the $\mathrm{C}=\mathrm{N}$ dynamic isomerization. Similar to previous examples, the complexation and fluorescent sensing mechanism of $\mathbf{1}$ with $\mathrm{Hg}^{2+}$ is depicted in Scheme 2.

To elucidate the complexation mode of $\mathbf{1}$ with $\mathrm{Hg}^{2+}$ ion, we synthesized 3 without the $\mathrm{C}=\mathrm{N}$ unit as a reference. As expected, upon addition of $\mathrm{Hg}^{2+}$ ion, no spectral change was noted as seen in Figure 5. It herewith should be noteworthy again that the $\mathrm{C}=\mathrm{N}$ group of coumarin 1 plays a crucial role in the complexation for $\mathrm{Hg}^{2+}$ ions. A Job plot experiment with 1 supports $1: 1$ complex formation of $\mathbf{1}$ for $\mathrm{Hg}^{2+}$ (Figure 6).

An important feature of $\mathbf{1}$ is to exhibit its high selectivity towards $\mathrm{Hg}^{2+}$ over other competitive species. UV/Vis spectral changes of 1 were investigated with addition of other miscellaneous cations including $\mathrm{Li}^{+}, \mathrm{Na}^{+}, \mathrm{K}^{+}, \mathrm{Rb}^{+}, \mathrm{Cs}^{+}, \mathrm{Cd}^{2+}, \mathrm{Ag}^{+}$, $\mathrm{Mg}^{2+}, \mathrm{Ca}^{2+}, \mathrm{Sr}^{2+}, \mathrm{Ba}^{2+}, \mathrm{Zn}^{2+}, \mathrm{Pb}^{2+}, \mathrm{Co}^{2+}$, and $\mathrm{Al}^{3+}$ (Figure 7). We found no changes of UV/Vis and fluorescence spectra of 1 . Competition experiments in the presence of other miscellaneous cations were not found to interfere the $\mathrm{Hg}^{2+}$ selectivity of $\mathbf{1}$. Therefore, compound $\mathbf{1}$ is thought to be a $\mathrm{Hg}^{2+}$ ion sensor applicable for the industrial and the envionmantal field.

\section{Experimental Section}

Instruments and reagents. All fluorescence and UV-Vis absorption spectra were recorded in RF-5301PC and S-3100 spectrophotometer, respectively. NMR and mass spectra were recorded at Varian instrument ( $400 \mathrm{MHz}$ ) and JMS-700 MStation mass spectrometer, respectively. All cationic compounds such as perchlorate salts of $\mathrm{Li}^{+}, \mathrm{Na}^{+}, \mathrm{K}^{+}, \mathrm{Rb}^{+}, \mathrm{Cs}^{+}, \mathrm{Cd}^{2+}, \mathrm{Ag}^{+}, \mathrm{Pb}^{2+}$, $\mathrm{Zn}^{2+}, \mathrm{Sr}^{2+}, \mathrm{Ba}^{2+}, \mathrm{Ca}^{2+}, \mathrm{Hg}^{2+}$, and $\mathrm{Al}^{3+}$ ions were purchased from Aldrich and used as received. All solvents were analytical reagents and from Duksan Pure Chemical Co., $\mathrm{Ltd}$. $\mathrm{CH}_{3} \mathrm{CN}$ for spectra detection was HPLC reagent without fluorescent impurity.

General procedure for fluorescence studies. Fluorescence spectra were recorded with a RF-5301PC spectrofluorophotometer. Stock solutions $(1.00 \mathrm{mM})$ of perchlorate salts were prepared in $\mathrm{CH}_{3} \mathrm{CN}$. Stock solutions of free $\mathbf{1}(0.040 \mathrm{mM})$ were prepared in $\mathrm{CH}_{3} \mathrm{CN}$. Excitations were carried out at $450 \mathrm{~nm}$ with all excitation slit widths is $3 \mathrm{~nm}$, that of emission is $3 \mathrm{~nm}$.

Job plot experiment. For the Job plot experiment, $1(20.0 \mu \mathrm{M})$ in $\mathrm{CH}_{3} \mathrm{CN}$ and perchlorate salts of $\mathrm{Hg}^{2+}(20.0 \mu \mathrm{M})$ in $\mathrm{CH}_{3} \mathrm{CN}$ were prepared as stock solutions. The concentrations of each $\mathrm{CH}_{3} \mathrm{CN}$ solution were varied, but the total volume was fixed at $4.0 \mathrm{~mL}$. After the mixture was shaken, the absorbance intensity at $450 \mathrm{~nm}$ was recorded.

\section{Synthesis.}

7-Diethylamino-3-(2-phenylhydrazono)methyl coumarine (1): A portion of $4(200 \mathrm{mg}, 1 \mathrm{mmol})$ and phenylhydrazine $(97$ $\mathrm{mg}, 1.1 \mathrm{mmol})$ were combined in hot absolute ethanol (20 $\mathrm{mL}$ ). The solution was stirred at reflux conditions for 4 hours, and the precipitate was filtrated, washed with hot absolute ethanol three times, then recrystallized with $\mathrm{CH}_{3} \mathrm{Cl} / \mathrm{C}_{2} \mathrm{H}_{5} \mathrm{OH}$ $(\mathrm{v} / \mathrm{v}, 1 / 3)$ to obtain orange crystal $1(215 \mathrm{mg})$ in $80 \%$ yield. ${ }^{1} \mathrm{H}$ NMR $\left(\mathrm{CDCl}_{3}, 400 \mathrm{MHz}\right) \delta 8.19\left(\mathrm{~s}, 1 \mathrm{H}, \mathrm{Ar}_{\text {cou }} H\right), 7.88(\mathrm{~s}, 1 \mathrm{H}$, $\left.\mathrm{Ar}_{\mathrm{cou}} H\right), 7.74\left(\mathrm{~s}, 1 \mathrm{H}, \mathrm{Ar}_{\mathrm{cou}} H\right), 7.36\left(\mathrm{~d}, 1 \mathrm{H}, \mathrm{Ar}_{\mathrm{cou}} H, J=8.84\right.$ $\mathrm{Hz}), 7.29$ (dd, $2 \mathrm{H}, \mathrm{Ar} H, J=7.06 \mathrm{~Hz}), 7.11$ (dd, $2 \mathrm{H}, \operatorname{Ar} H, J=$ $7.44 \mathrm{~Hz}$ ), 6.87 (t, $1 \mathrm{H}, \mathrm{Ar} H, J=7.41 \mathrm{~Hz}), 6.61$ (dd, $1 \mathrm{H}, \mathrm{Ar}_{\text {cou }} H$, $J=8.73 \mathrm{~Hz}), 6.50\left(\mathrm{~d}, 1 \mathrm{H}, \mathrm{Ar}_{\text {cou }} H, J=2.36 \mathrm{~Hz}\right), 3.43(\mathrm{q}, 4 \mathrm{H}$, $\left.\mathrm{NCH}_{2} \mathrm{CH}_{3}, J=7.10 \mathrm{~Hz}\right), 1.22\left(\mathrm{t}, 6 \mathrm{H}, \mathrm{NCH}_{2} \mathrm{CH}_{3}, J=7.10 \mathrm{~Hz}\right)$. ${ }^{13} \mathrm{CNMR}\left(\mathrm{CDCl}_{3}, 100 \mathrm{MHz}\right) \delta 161.9(1 \mathrm{C}), 156.0(1 \mathrm{C}), 150.0(1$ C), 145.4 (1 C), 144.3 (1 C), 135.9 (1 C), 135.8 (1 C), 131.7 (1 C), 131.6 (1 C), 129.5 (1 C), 129.3 (1 C), 120.3 (1 C), 112.7 (1 C), 110.2 (1 C), 108.2 (1 C), 97.1 (1 C), 45.3 (2 C), 12.3 (2 C). IR (deposit from $\mathrm{CH}_{2} \mathrm{Cl}_{2}$ solution on a $\mathrm{KBr}$ plate, $\mathrm{cm}^{-1}$ ): 1698 $\left(\mathrm{C}=\mathrm{O}\right.$ br), $1616(\mathrm{C}=\mathrm{N})$. FAB MS $m / z\left(\mathrm{M}^{+}\right)$: calcd, 335.4, found, 335.00 .

7-Diethylamino-3-(2-(2,4-dinitrophenyl)hydrazono)methyl coumarine (2): Compound 4 (245 mg, $1 \mathrm{mmol}$ ) and (2,4-dinitrophenyl)hydrazine (218 mg, $1.1 \mathrm{mmol}$ ) were combined in absolute ethanol $(30 \mathrm{~mL})$ and stirred for 4 hours under reflux conditions. The precipitate was filtrated, washed with hot absolute ethanol three times, then recrystallized with $\mathrm{CH}_{3} \mathrm{OH}$ to obtain red crystal $2(344.6 \mathrm{mg})$ in $81 \%$ yield. ${ }^{1} \mathrm{H}$ NMR $\left(\mathrm{CDCl}_{3}, 400\right.$ $\mathrm{MHz}) \delta 11.40(\mathrm{~s}, 1 \mathrm{H}, \mathrm{NH}), 9.16(\mathrm{~d}, 1 \mathrm{H}, \mathrm{Ar} H, J=2.58 \mathrm{~Hz}), 8.35$ (dd, $1 \mathrm{H}, \mathrm{Ar} H, J=9.22 \mathrm{~Hz}), 8.33\left(\mathrm{~d}, 2 \mathrm{H}, \mathrm{Ar}_{\text {cou }} H, J=11.51 \mathrm{~Hz}\right.$ ), 8.07 (d, $1 \mathrm{H}, \mathrm{Ar} H, J=9.58 \mathrm{~Hz}), 7.42$ (d, $1 \mathrm{H}, \mathrm{Ar}_{\mathrm{cou}} H, J=8.90$ $\mathrm{Hz}), 6.67\left(\mathrm{dd}, 1 \mathrm{H}, \mathrm{Ar}_{\mathrm{cou}} H, J=8.90 \mathrm{~Hz}\right), 6.53\left(\mathrm{~d}, 1 \mathrm{H}, \mathrm{Ar}_{\mathrm{cou}} H\right.$, $J=2.34 \mathrm{~Hz}), 3.47\left(\mathrm{q}, 4 \mathrm{H}, \mathrm{NCH}_{2} \mathrm{CH}_{3}, J=7.14 \mathrm{~Hz}\right), 1.26(\mathrm{t}, 6 \mathrm{H}$, $\left.\mathrm{NCH}_{2} \mathrm{CH}_{3}, J=7.11 \mathrm{~Hz}\right) .{ }^{13} \mathrm{C} \mathrm{NMR}\left(\mathrm{CDCl}_{3}, 100 \mathrm{MHz}\right) \delta 161.7$ (1 C), 157.5 (1 C), 152.1 (1 C), 144.7 (1 C), 143.4 (1 C), 139.8 (1 C), 138.3 (1 C), 130.8 (1 C), 130.1 (1 C), 129.5 (1 C), 123.9 (1 C), $116.8(1 \mathrm{C}), 112.5(1 \mathrm{C}), 110.2(1 \mathrm{C}), 109.0(1 \mathrm{C}), 97.6(1 \mathrm{C})$, $45.4(2 \mathrm{C}), 12.7(2 \mathrm{C})$. IR (deposit from $\mathrm{CH}_{2} \mathrm{Cl}_{2}$ solution on a $\mathrm{KBr}$ plate, $\left.\mathrm{cm}^{-1}\right): 1715(\mathrm{C}=\mathrm{O}$ br $), 1586(\mathrm{C}=\mathrm{N}), 1517(\mathrm{~N}-\mathrm{O})$. FAB MS $m / z\left(\mathrm{M}^{+}\right)$: calcd, 425.39. found, 425.00 .

Acknowledgments. This work was supported by the Creative Research Initiative program from National Research Foundation and by the Sookmyung Women's University Research Grant 2008. This paper is dedicated with respect and affection to the late Professor Chi Sun Hahn, an inspiring teacher and mentor, for his contributions to the field of organic chemistry in Korea.

\section{References}

1. (a) de Silva, A. P.; Gunaratne, H. Q. N.; Gunnlaugsson, T.; Huxley, 
A. J. M.; McCoy, C. P.; Rademacher, J. T.; Rice, T. E. Chem. Rev. 1997, 97, 1515. (b) Valeur, B.; Leray, I. Coord. Chem. Rev. 2000, 205, 3. (c) Prodi, L.; Bolletta, F.; Montalti, M.; Zaccheroni, N. Coord. Chem. Rev. 2000, 205, 59. (d) Boening, D. W. Chemosphere 2000, 40, 1335. (e) Kim, J. S.; Quang, D. T. Chem. Rev. 2007, 107, 3780. (f) Lee, Y. O.; Choi, Y. H.; Kim, J. S. Bull. Kor. Chem. Soc. 2007, 28(1), 151. (g) Kim, H. J.; Kim, S. H.; Quang, D. T.; Kim, J. H.; Suh, I. W.; Kim, J. S. Bull. Kor. Chem. Soc. 2007, 28(5), 811. (h) Kim, S. K.; Lee, S. H.; Lee, J. Y.; Bartsch, R. A.; Kim, J. S. J. Am. Chem. Soc. 2004, 126, 16499-16506. (i) Lee, M. H.; Wu, J.-S.; Lee, J. W.; Jung, J. H.; Kim, J. S. Org. Lett. 2007, 9, 2501. (j) Lee, M. H.; Cho, B.-K.; Yoon, J.; Kim, J. S. Org. Lett. 2007, 9, 4515. (k) Lee, M. H.; Lee, S. W.; Kim, S. H.; Kang, C.; Kim, J. S. Org. Lett. 2009, 11, 2101.

2. (a) Renzoni, A.; Zino, F.; Franchi, E. Environ. Res. 1998, 77, 68. (b) Fabbrizzi, L.; Licchelli, M.; Pallavicini, P.; Perrotti, A.; Sacchi, D. Angew. Chem., Int. Ed. Engl. 1994, 33, 1975. (c) Ramachandram, B.; Samanta, A. Chem. Commun. 1997, 1037. (d) Singh, A.; Yao, Q.; Tong, L.; Still, W. C.; Sames, D. Tetrahedron Lett. 2000, 41, 9601. (e) Zheng, Y.; Huo, Q.; Kele, P. F.; Andrepoulos, M.; Pham, S. M.; Leblanc, R. M. Org. Lett. 2001, 3, 3277. (f) Beltramello, M.; Gatos, M.; Mancin, F.; Tecilla, P.; Tonellato, U. Tetrahedron Lett. 2001, 42, 9143. (g) Kaur, S.; Kumar, S. Chem. Commun. 2002, 2840. (h) Qi, X.; Jun, E. J.; Xu, L.; Kim, S.-J.; Hong, J. S. J.; Yoon, Y. J.; Yoon, J. J. Org. Chem. 2006, 71, 2881. (i) Lee, M. H.; Wu, J. -S.; Lee, J. W.; Jung, J. H.; Kim, J. S. Org. Lett. 2007, 9, 2501. (j)
Wu, J.-S.; Hwang, I.-C.; Kim, K. S.; Kim, J. S. Org. Lett. 2007, 9, 907. (k) Kim, H. N.; Lee, M. H.; Kim, H. J.; Kim, J. S.; Yoon, J. Chem. Soc. Rev. 2008, 37, 1465.

3. (a) Morris, M. D.; Whitlock, L. R. Anal. Chem. 1967, 39, 1180. (b) Kimura, K.; Yajima, S.; Tatsumi, K.; Yokoyama, M.; Oue, M. Anal. Chem. 2000, 72, 5290. (c) Aravindhan, R.; Madhan, B.; Rao, J. R.; Nair, B. U.; Ramasami, T. Environ. Sci. Technol. 2004, 38, 300. (d) Gunnlaugsson, T.; Leonard, J. P.; Murray, N. S. Org. Lett. 2004, 6, 1557.

4. (a) Brun, M. P.; Bischoff, L.; Garby, C. Angew. Chem., Int. Ed. 2004, 43, 3432. (b) Geissler, D.; Antonenko, Y. N.; Schmidt, R.; Keller, S.; Krylova, O. O.; Wiesner, B.; Bendig, J.; Pohl, P.; Hagen, V. Angew. Chem., Int. Ed. 2005, 44, 1195. (c) Feng, Y.; Burgess, K.; Pledger, D.; Cairns, N. Bioorg. Med. Chem. Lett. 1998, 8, 881. (d) John, F. T.; Ranjith, V. J. Heterocycl. Chem. 2000, 37, 1447. (e) Kele, P.; Orbulescu, J.; Calhoun, T. L.; Gawley, R. E. Tetrahedron Lett. 2002, 43, 4413. (f) Kulkarni, M. V.; Shastri, L. A.; Ghate, M. D. Indian J. Chem. 2004, 43B, 2416.

5. Sheng, R. L.; Wang, P. F.; Liu, W. M.; Wu, X. H.; Wu, S. K. Sensor Actuat. B 2008, 15, 128.

6. Wu, J. S.; Liu, W. M.; Zhuang, X. Q.; Wang, F.; Wang, P. F.; Tao, S. L.; Zhang, X. H.; Wu, S. K.; Lee, S. T. Org. Lett. 2007, 9, 33.

7. (a) Maruyama, S.; Kikuchi, K.; Hirano, T.; Urano, Y.; Nagano, T. J. Am. Chem. Soc. 2002, 124, 10650. (b) Mei, Y.; Bentley, P. A. Bioorg. Med. Chem. Lett. 2006, 16, 3131. (c) Ji, Z. J.; Wu, Y.-M.; Wu, F.-Y. Chem. Lett. 2006, 35, 950. 